\title{
PENGARUH LEVEL LEVERAGE OPERASI DAN LEVEL LEVERAGE KEUANGAN TERHADAP RISIKO SISTEMATIS (Studi Kasus Pada Perusahaan Manufaktur)
}

Oleh:

Kartini ')

Nevsi Rizki Herine Putri ")

\begin{tabular}{c|c|c} 
& Nevsi Rizki Herine Putri ") & \\
\hline & ABSTRAKSI & \\
\hline & Untuk menambah laba perusahaan, seorang manajer perusahaan harus
\end{tabular}
mempertimbangkan penggunaan leverage. Leverage adalah pengsunaan biaya tetap dalam upaya meningkatkan laba. Leverage ada dua macam lezerage operasi dan leverage keuangan. Yang mana penggunaannya akan sangat berpengaruh terhadap besar kecilnya risiko dan laba yang akan didapatkan.

Studi ini meneliti tentang pengaruh leverage operasi dan leverage keuangan terhadap risiko sistematis studi pada perusahaan manufatur yang terdaftar di $L Q$ 45. Tujuan dari tugas akhir ini adalah mengetahui pengaruh leverage operasi dan leverage keuangan terhadap risiko sistematis. Metode penelitian yang digunakan - adalah dengan menganalisis besarnya risiko sistematis masing-masing perusahaan, menganalisis besarnya tingknt leverage operasi dengan analisis degree of operating leverage (DOL), menganalisa besarnya tingkat leverage keuangan dengan analisis degree of finance leverage (DFL).

Hasil dari perhitungan tingkat leverage operasi yang diukur dengan menggunakan rasio antara persentase perubahan net operating income dengan perubahan net sales menunjukan bahwa terdapat pengaruh positif signifikan terhadap risiko sistematis. Sedangkan hasil dari perhitungan tingkat leverage keuangan yang diukur dengan menggunakan rasio antara persentase perubahan earning per share dengan persentase perubahan earning before interest and taxes menunjukan bahwa terdapat pengaruh negatif signifikan terhadap risiko sistematis. Sedangkan secera simultan leverage operasi dan leverage keuangan berpengarth signifikan terhadap risiko sistematis. Beberapa penelitian sebelumnya memiliki hasil yang sama dan juga berbeda dengan hasil penelitian ini. Faktor-faktor yang mungkin menyebabkan ketidaksamaan ini meliputi metode penel itian yang berbeda, sampel dan alat analisis pengukuran variabel yang berbeda.

*) Kartiṇi adalah Dosen Fakultas Ekonomi Universitas Islam Indonesia

*) Nevsi Rizki Herine Putri adalah Alumnus Universitas Islam Indonesia 


\section{A. LATAR BELAKANG MASALAH}

Risiko menunjukan hubungan antara nilai dan hasil, yang berkaitan dengan ketidakpastian tingkat hasil investasi. Seorang menajer keuangan harus mempertimbangkan keputusan-keputusan yang akan diambil agar nilai dan hasil bisa didapat secara maksimal. Setiap keputusan yang diambil, baik itu keputusan investasi ataupun keputusan pembelanjaan akan mengakibatkan biaya tetap. Besar kecilnya biaya tetap sebuah perusahaan didalam operasinya akan mempengaruhi risiko bisnisnya. Jika biaya tetap tinggi, bahkan penurunari penjualan yang kecil sekalipun dapat menyebabkan terjadinya penurunan ROE yang cukup besar. Jadi, semakin tinggi biaya tetap sebuah perusahaan, maka semakin besar risiko bisnisnya. Untuk mengupayakan peningkatan laba yang menggunakan biaya tetap sering disebut dengan leverage.

Leverage adalah penggunaan biaya tetap dalam upaya meningkatkan laba. Manajer keuangan lagi-lagi harus berhati-hati dalam melakukan pengambilan keputusan leverage. Ada dua macam leverage, yaitu leverage operasi dan leverage keuangan. Leverage operasi dapat digunakan untuk mengukur seberapa besar penggunaan biaya tetap operasi dalam suatu perusahaan. Leverage operasi merupakan perbandingan antara biaya tetap dengan biaya variable perusahaan. Sedangkan leverage keuangan digunakan untuk mengukur seberapa besar aktiva perusahaan dibiayai dengan hutang. Kedua jenis leverage ini saling berkaitan. Misalnya, jika sebuah perusahaan mengurangi leverage operasinya, mungkin akan menyebabkan kenaikan dalam penggunaan leverage keuangan yang optimal. Di lain pihak, jika diputuskan untuk meningkatkan leverage operasi, struktur modal yang optimal mungkin memeriukan lebih biaya.

Banyak studi yang sudah dilakukan untuk menguji hubungan antara variabel-variabel yang berkaitan dalam penentuan risiko sistematis. Insiatiningsih (2001) menunjukan bahwa tingkat leverage operasi (DOL) berpengaruh positif terhadap beta saham (â), namun demikian pada tingkat kepercayaan $95 \%$ pengaruh tersebut dapat diabaikan. Sedangkan untuk tingkat leverage keuangan (DFL) berpengaruh positif terhadap beta saham (â), namun demikian pada tingkat kepercayaan $95 \%$ pengaruh tesebut dapat diabaikan. Studi lainnya, misalnya Isfenti Sadila (2003) menunjukan bahwa antara variable laten leverage keuangan dengan risiko sistematis terdapat pengaruh negative tetapi tidak signifikan.

Berbeda dengan penelitian yang dilakukan oleh Sufjati dan Ainun Na'im (1998) yang menyatakan bahwa leverage operasi tidak mempunyai pengaruh yang signifikan terhadap beta. Ini berarti struktur biaya perusahaan tidak menentukan risiko sistematis. Sedangkan untuk leverage keuangan menunjukkan pengaruh yang negative dan signifikan terhadap beta, artinya semakin tinggi leverage keuangan perusahaan semakin rendah risiko yang ditanggung oleh pemegang saham.

Penelitian ini hanya akan mengulang kembali penelitian yang sudah ada, karena hasil dari setiap penelitian yang berbeda-beda, menarik peneliti untuk meneliti lebih lanjut. 
Kartini dan Nevsi Rizki Herine Putri: Pengaruh Level Leverage Operasi dan Level...

Dari penjelasan di atas, dapat diambil rumusan masalah sebagai berikut:

Bagaimana pengaruh tingkat leverage operasi dan leverage keuangan i terhadap risiko sistematis?

\begin{tabular}{l|l|l|l} 
& terhadap risiko sistematis? & \\
\hline B. & TINJAUAN PUSTAKA DAN PERUMUSAN HIPOTESIS & \\
\hline & Teori Risiko &
\end{tabular}

Risiko adalah sesuatu kondisi ketidakpastian (Mamduh Hanafi, 2006). Risiko merupakan faktor penting dalam keputusan investasi dan dalam analisis keuangan, terutama berkaitan dengan bagaimana pengaruh risiko terhadap harga pasar dan tingkat pendapatan. Seorang manajer keuangan harus mengetahui berapa tingkat pendapatan yang diharapkan investor sebagai ganti risiko yang akan mereka tanggung dengan memiliki sebuah saham. Menurut Bringham risiko didefinisikan sebagai kemungkinan keuntungan yang diterima lebih kecil dari keuntungan yang diharapkan. Menurut Jones bahwa risiko adalah kemungkinan pendapaan yang diterima (actual return) dalam suatu investasi berbeda dengan pendapatan yang diharapkan (expected return). Risiko ini memiliki dua jenis, yaitu systematic risk (risiko sistematik) dan unsystematic risk (risiko ansistematik). Risiko sistematik adalah risiko yang tidak dapat dihilangkan dengan jalan diversifikasi dalam portofolio yang besar dan mempengaruhi semua perusahaan atau industri. Sedangkan risiko ansistematik adalah risiko yang dapat dihilangkan dengan menggunakan diversifikasi dalam portofolio yang besar. Risiko sistematik ini yang akan digunakan oleh peneliti sebagai variable dependen dalam penelitian. Karena risiko ini akan mempengaruhi pendapatan atau laba dan pendapatan bagi para pemegang saham.

\section{Leverage Operasi}

Leverage operasi berkaitan dengan penggunaan biaya tetap perusahaan dalam operasinya. Menurut J. Fred Weston dan Brigham (1983) Leverage operasi adalah seberapa besar perusahaan menggunakan biaya operasi tetap (biaya tetap: pabrik, penjualan dan administrasi). Jika biaya tetap tinggi, bahkan penurunan penjualan yang kecil sekalipun dapat menyebabkan terjadinya penurunan ROE yang cukup besar. Jadi, jika hal-hal lain dianggap konstan, semakin tinggi biaya tetap sebuah perusahaan, maka semakin besar risiko bisnisnya. Biaya tetap yang tinggi umumnya dikaitkan dengan perusahaan-perusahaan dan industri-industri yang sangat terotomatisasi dan intensif modal. Akan tetapi, bisnis-bisnis yang mempekerjakan karyawan yang sangat terampil yang harus dipertahankan dan dibayar bahkan dalam keadaan resesi juga akan memiliki biaya pengembangan produk yang tinggi, karena amortisasi dari biaya pengembangan merupakan salah satu unsur dari biaya tetap. Jika sebagian besar biaya adalah biaya tetap, maka perusahaan tersebut dikatakan memiliki tingkat leverage operasi yang tinggi. Faktor kunci yang harus dipertimbangkan oleh manajemen dalam menentukan operasi leveragenya ialah untung ruginya antara alat-alat otomatis (biaya penyusutan yang besar dari biaya tetap pabrik) dengan tenaga kerja. Arti leverage operasi yang lebih khusus adalah pengaruh perubahan 
volume terhadap pendapatan bersih operasi. Untuk mengukur tingkat leverage operasi digunakan persentase perubahan laba operasi yang dihasilkan dari suatu persentase perubahan dalam unit yang dijual (J. Fred Weston dan Brigham, 1998). Tingkat leverage operasi disebut juga dengan degree of operating leverage (DOL). Tingkat leverage operasi mengukur pengaruh terhadap laba dari segala perubahan volume keluaran yaitu baik itu kenaikan ataupun penurunan volume penjualan. Pengukuran tersebut memiliki kegunaan yang penting untuk sejumlah bidang usaha dan kebijaksanaan keuangan. Tingkat leverage operasi yang tinggi berarti meningkatkan laba dengan cara menambah volume.

\section{Leverage Keuangan}

Leverage keuangan terjadi pada saat perusahaan menggunakan sumber dana yang menimbulkan beban tetap. Apabila perusahaan menggunakan hutang, maka perusahaan harus membayar bunga. Bunga ini harus dibayar, berapapun keuntungan operasi perusahaan. Karena itu analisis leverage keuangan memusatkan perhatian pada perubahan laba setelah pajak sebagai akibat perubahan laba operasi. Leverage keuangan yang berarti mempergunakan utang untuk memperbesar tingkat hasil (return) atas hasil yang biasa diperoleh atas aktiva. Bila hasil atas aktiva melebihi biaya utang, maka leverage merupakan pedang bermata dua dan jika hasil atas aktiva lebih kecil daripada hutang, maka leverage mengurangi hasil atas modal. Semakin besar leverage yang digunakan oleh perusahaan akan semakin besar pula pengurangan terhadap modal ini. Sebagai akibatnya, leverage dapat dipergunakan untuk memperbesar hasil para pemegang saham, tetapi hal ini dipakai dengan adanya risiko akan meningkatkan kerugian diperbesar oleh leverage, dan semakin besar akan semakin besar pula bahaya pengurangan terhadap hasilnya. Cara mengukur efek leverage adalah dengan menggunakan tingkat leverage keuangan (DFL). Menurut $\mathrm{J}$. Weston tingkat leverage keuangan adalah suatu ukuran titik elastisitas yang diartikan sebagai rasio persentase perubahan dalam laba bersih dibagi dengan persentase perubahan dalam laba sebelum bunga dan pajak. Apabila DFL semakin besar, maka fluktuasi (positif atau negative) pada laba per lembar saham semakin besar. pemegang saham terpaksa menerima variasi pengembalian yang lebih besar apabila manajemen perusahaan memilih untukk menggunkan leverage keuangan yang lebih besar daripada yang lebih kecil. Ukuran DFL memungkinkan variasi tersebut dikuantifisir.

\section{Penelitian Terdahulu}

Penelitian yang sudah dilakukan oleh beberapa peneliti terdahulu mengacu pada beberapa variabel-variabel dan cara perhitungan yang berbeda. Hasil penelitian yang berhasil dirangkum peneliti adalah sebagai berikut:

Sufiyati dan Ainun Na'im (1998), Leveragè keuangan memiliki pengaruh negatif yang signifikan terhadap beta ketika leverage diukur dengan EBIT, dan menunjukan tidak ada pengaruh yang signifikan ketika leverage diukur dengan NOI. Leverage operasi tidak mempunyai pengaruh yang signifikan terhadap beta.

Isfenti Sadalia (2003), penelitian yang dilakukan dengan judul "pengaruh leverage keuangan dan kebijakan keuangan terhadap risiko sistematis dan 
Kartini dan Nevsi Rizki Herine Putri: Pengaruh Level Leverage Operasi dan Level:.:

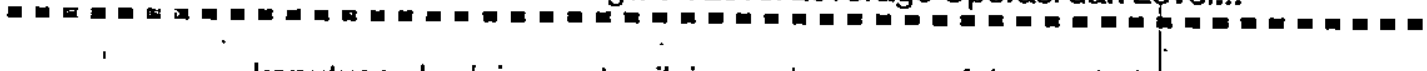

keputusan hedging serta nilai perushaan manufaktur terbuka" dengan asumsi untuk hubungan leverage keuangan dan risiko sistematis bahwa terdapat pengaruh faktor leverage keuangan terhadap risiko sistematis pada perusahàan manufaktur terbuka Indonesia. Hasil analisis menunjukan bahwa antara variable leverage keuangan dengan risiko sistematis terdapat pengaruh negatif tetapi tidak signifikan. .

Insiatiningsih (1998), untuk tingkat leverage operasi (DOL) yang diukur -melalui rașio antara perubahan net operating income dengan peubahan net sales berpengaruh positif terhadap beta saham, namun demikian pada tingkat kepercayaan $95 \%$ pengaruh tersebut dapat diabaikan. Sedangkan tingkat leveragje keuangan (DFL) yang diukur melalui rasio antara perubahan eaming after taxes dengan perubahan earning before interest and taxes berpengaruh positif terhadap beta saham, namun demikian pada tingkat kepercayaan $95 \%$ pengaruh tersebut dapat diabaikan.
\end{abstract}

\title{
Pengajuan Hipotesis
}

Berdasarkan beberapa penelitian yang ada, maka peneliti ingin meneliti lebih lanjut tentang penganuh leverage operasi dan leverage keuangan terhadap risiko sistematis. Maka hipotesis yang akan di uji dalain penelitian adalah sebagai berikut: pertama, leverage operasi berpengaruh pos tif terhadap risiko sistematis. Kedua, leverage keuangan berpengaruh positif terhadap risiko sistematis.

\section{METODE PENELITIAN}

Perusahaan-perusahaan yang digunakan dalam penelitian ini adalah perusahaan manufaktur terbuka Indonesia yang sahamnya aktif di BEJ dan selama dalam tahun 2003-2007 berturut-turut masuk dalam daftar LQ-45.

Kriteria kedua yaitu kriteria yang berhubungan dengan nilai beta saham, yaitu hanya perusahaan-perusahaan yang mempunyai beta saham pósitif saja yang dijadikan sampel. Hal ini dilakukan agar diperoleh hasil estimasi beta yang lebih baik. Berdasarkan kriteria kedua ini, dari 9 perusahaan diperoleh 8 perusahaan yang menjadi sampel dalam penelitian ini.

\section{Pengukuran Variabel Dependen: Risiko Sistematis (Beta)}

Dalam penelitian ini risiko sistematis diukur dengan beta. Cara perhitung beta saham menggunakan model indeks tunggal (single index model). Rumusan beta saham sebagai berikut:

$$
\mathrm{R}_{i}=\alpha_{i}+\beta_{i} \mathrm{R}_{M}+\mathrm{e}_{i}
$$

Dimana $\mathrm{R}=$ return saham $\mathrm{i}, \mathrm{R}=$ return portofolio pasar yang diukur melalui return IHSG. Jika besarya return saham dan retum portofolio pasar sudah dihitung, maka besarnya beta saham dapat dihitung dengan menggunakan 
teknik regresi yaitu sebagai slope garis regresi. Untuk mendapatkan nilai beta saham, return saham dan return portofolio pasar terlebih dahulu dihitung dengan menggunakan rumusan sebagai berikut:

Return saham

Return portofolio pasar

$$
: \mathrm{R}_{i}=\frac{P_{t}-P_{t-1}}{p_{t-1}}
$$$$
: \mathrm{R}_{M}=\frac{I H S G_{t}-I H S G_{t-1}}{I H S G_{t-1}}
$$

Return saham diperoleh dari harga saham harian selama 5 tahun. Return portofolio pasar juga diperoleh secara harian selama 5 tahun. Beta saham dihitung berdasarkan hasil return saham harian dan return pasar harian, yang diregrasi dalam periode tahunan selama 5 tahun.

\section{Pengukuran Variabel Independen}

\section{- Leverage Operasi}

Leverage operasi dalam penelitian ini dihitung dengan tingkat leverage operasi atau sering disingkat dengan $\mathrm{DOL}$ (degree of operating leverage). DOL dihitung melalui rasio antara perubahan net operating income dengan perubahan net sales atau sebagai berikut:

$$
\mathrm{DOL}=\frac{\Delta N O I / N O I}{\Delta \text { sales } / \text { sales }}
$$

Dimana NOI diperoleh dari hasil penjualan sebelum dikurangi biaya-biaya operasi.

\section{- Leverage Keuangan}

Leverage keuangan dalam penelitian ini dihitung dengan menggunakan tingkat leverage keuangan atau sering disebut dengan DFL (degree of financial leverage). DFL dihitung melalui rasio antara perubahan eaming per share dengan perubahan earning before interest and taxes (EBIT), atau sebagai berikut ini:

$$
\mathrm{DFL}=\frac{\triangle E P S / E P S}{\triangle E B I T / E B I T}
$$

EBIT diperoleh dari NOI disesuaikan dengan beban dan pendapatan non operasi tetapi sebelum beban pajak dan bunga. EPS adalah laba untuk para pemegang saham.

\section{Pengujian Asumsi Klasik}

Terdapat tiga uji asumsi klasik yang digunakan dalam penelitian ini, yaitu heteroskedatisitas, autokorelasi, dan multikolinearitas. Untuk uji tersebut, hasil yang diinginkan adalah bahwa semua uji tidak bermasalah. Untuk meyakinkan 
bahwa model yang diperoleh mempunyai kemampuan prediktif yang baik maka terlebih dahulu model tersebut harus diuji apakah model telah memenuhi asumsiasumsi-yang melandasinya. Apabila terjadi masalah maka data yang diperoleh tidak banyak bermanfaat dalam pengambilan keputusan.

- Uji Multikolinearitas

Uji multikolinearitas merupakan uji terhadap adanya masalah korelasi yang -sempurna antara suatu variabel independen (regresori) dengan variabel independen yang lain. Beberapa konsekuensi praktis yang timbul sebagai akibat adanya multikolinearitas ini adalah kesalahan standar penaksir semakin besar, dan probabilitas untuk hipotesis yang salah menjadi semakin besar.

Cara menentukan adanya masalah atau tidak, dengan memperhatikan nilai koefisien antar variabel. Apabila hasil perhitungan koefisien antar variabel lebih besar dari 0,89 maka ada masalah pada multikolinearitas.

\section{- Uji Heteroskedatisitas.}

Uji heteroskedatisitas merupakan pengujian dimana pada nilai variabel independen tertentu yang dipilih masing-masing kesalahan mempunyai nilai varian yang sama (homokedastisitas) (Gujarati, 1995). Uji heteroskedastisitas ini dilakukan dengan uji White. Uji White menggunakan residual kuadrat sebagai variabel dependen, dan variabel independennya terdiri atas variabel independen yang sudah ada, ditambah dengan kuadrat variabel independen, ditambah lagi dengan perkalian dua variabel independen. Maka persamaan dari regresinya sebagai| berikut:

$$
b e t a=a+b D O L+b_{2} D F L+b_{3} D O L^{2}+b_{4} D F L^{2}+b_{5}(D O L)(D F L)
$$

Jika model yang dipilih ternyata terdapat masalah heteroskedatisitas, maka nilai-nilai estimator dari model tersebut tidak efisien meskipun estimator tersebut tidak bias dan konsisten (Gujarati, 1995)

Cara penilaian uji ini apakah terbebas dari masalah dengan membandingkan antara nilai probabilitas $(p)$ dengan taraf $\operatorname{signifikan}^{-}(\alpha)$.

Apabila $p<\alpha$ maka artinya variabel leverage keuangan dan leverage operasi secara bersama-sama ada masalah dengan pengujian heteroskedatisitas.

Apabila $p>\alpha$ maka artinya variabel leverage operasi dan leverage keuangan secara bersama-sama tidak ada gejala masalah heteroskedatisitas.

Nilai á dalam penelitian ini adalah sebesar 0,050 dengan tingkat keyakinan $95 \%$.

\section{Uji Autokorelasi}

Uji Autokorelasi adalah hubungan antara residual satu observasi dengan residual observasi lainnya. Autokorelasi lebih mudah /timbul pada data yang bersifat runtut waktu, karena berdasarkan sifatnya, data masa sekarang dipengaruhi oleh data pada masa-masa sebelumnya. Meskipun demikian, tetap dimungkinkan autokorelasi dijumpai pada data yang bersifat 
antarobjek. Dalam penelitian ini, peneliti menggunakan uji autokorelasi dengan metode Durbin-Watson. Uji Durbin-Watson merupakan salah satu uji yang banyak dipakai untuk mengetahui ada tidaknya autokorelasi. Untuk mengukur tingkat masalah, uji Durbin-Watson menggunakan tabel yang menggambarkan koefisien DW. Nilai d akan berada dikisaran 0 hingga 4. Tabel untuk mengukur koefisien adalah sebagai berikut:

Tabel 1. Menunjukan koefisien Durbin-Watson

\begin{tabular}{|l|l|l|l|l|}
\hline $\begin{array}{l}\text { Auto korelasi } \\
\text { positif }\end{array}$ & $\begin{array}{l}\text { Tidak dapat } \\
\text { diputuskan }\end{array}$ & $\begin{array}{l}\text { Tidak ada } \\
\text { autokorelasi }\end{array}$ & $\begin{array}{l}\text { Tidak dapat } \\
\text { diputuskan }\end{array}$ & $\begin{array}{l}\text { Autokorelsi } \\
\text { negatif }\end{array}$ \\
\hline 0
\end{tabular}

Untuk mendapatkan model yang terbebas dari masalah, maka nilai dari perhitungan hasil harus berada pada angka antara 1,54-2,46. Apabila nilai koefisien DW tidak terletak di antara nilai tersebut, maka model terdapat masalah dan perlu dilakukan perbaikan.

\section{HASIL PENELITIAN DAN PEMBAHASAN}

Dari 9 perusahaan diperoleh 8 perusahaan yang menjadi sampel perusahaan manufaktur, adalah sebagai berikut: Asrta Internasional Tbk (ASII), Gudang Garam Tbk (GGRM), Gajah Tunggal Tbk (GJLT), Indofood Tbk (INDF), Indah Kiat Pulp \& Paper Tbk (INKP), indocement Tunggal Prakarsa Tbk (INTP), Kalbe Farma Tbk (KLBF), Semen Cibinong Tbk (SMCB).

\section{Perhitungan Variabel-Variabel}

- Variabel Dependen: Risiko Sistematis (Beta)

Dari perhitungan beta menggunakan bantuan Perangkat Lunak Komputer, maka didapatkan hasil sebagai berikut:

Tabel 2. Menunjukan Nilai Beta

\begin{tabular}{|l|l|l|l|}
\hline Nama & \multicolumn{3}{|l|}{ Beta } \\
\hline Saham & 2005 & 2006 & 2007 \\
\hline ASII $\cdot$ & 0.98005 & 1.15899 & 1.04529 \\
\hline GGRM & 0.47504 & 0.44342 & 0.3265 \\
\hline GJTL & 1.33011 & 1.01941 & 0.75009 \\
\hline INKP & 0.93583 & 0.8036 & 0.80262 \\
\hline INTP & 1.03233 & 0.98587 & 0.73305 \\
\hline KLBF & 0.62817 & 0.76593 & 0.55604 \\
\hline SMCB & 0.85691 & 0.90247 & 0.9488 \\
\hline UNVR & 0.14156 & 0.62063 & 0.79573 \\
\hline
\end{tabular}

Sumber: Hasil Penelitian 
Kartini dan Nevsi Rizki Herine Putri: Pengaruh Level Leverage Operasi dan Leveli:.;

Leverage Operasi

Hasil perhitungan DOL adalah sebagai berikut:

Tabel 3. Menunjukan Nilai DOL

\begin{tabular}{|l|l|l|l|}
\hline Nama & \multicolumn{3}{|l|}{ DOL } \\
\hline Saham & 2005 & 2006 & 2007 \\
\hline ASII & -0.81682 & 3.46907 & 3.86258 \\
\hline GGRM & 3.45202 & -5.069 & 2.23661 \\
\hline GJTL & 1.39472 & -0.7861 & 3.7754 \\
\hline INKP & -8.2073 & 84.8723 & 4.98703 \\
\hline INTP & 2.13418 & -0.9194 & 3.0689 \\
\hline KLBF & 0.61791 & 0.31079 & 0.3527 \\
\hline SMCB & -11.11 & 118.323 & 327.116 \\
\hline UNVR & -0.0385 & 1.48384 & 1.31588 \\
\hline
\end{tabular}

Sumber: Hasil Penelitian

- Leverage Keuangan

Hasil Perhitungan DFL sebagai berikut:

Tabel 4. Menunjukan Nilai DFL

\begin{tabular}{|l|l|l|l|}
\hline Nama & \multicolumn{3}{|l|}{ DFL } \\
\hline Saham & 2005 & 2006 & 2007 \\
\hline ASII & 0.3927 & 0.85816 & 0.65815 \\
\hline GGRM $\cdot$ & 1.02519 & 1.14192 & 1.14989 \\
\hline GJTL & 1.0491 & -3.2457 & 0.54264 \\
\hline INKP & 0.90707 & 9.1551 & 0.2784 \\
\hline INTP & 1.09126 & 0.99478 & 1.0219 \\
\hline KLBF & 0.62453 & 1.0991 & 0.47444 \\
\hline SMCB & 0.57446 & 0.6679 & 0.19184 \\
\hline UNVR & 0.74862 & 1.00939 & 0.94797 \\
\hline \multicolumn{5}{|c|}{ Sumber: Hasil Penelitian } \\
\hline
\end{tabular}

\section{Uji Asumsi Klasik}

Tiga asumsi klásik penting yang melandasi analisis regresi adalah asumsi tidak terjadinya multikolenearitas, tidak terjadi heteroskedatisitas, serta tidak terjadi autokorelasi.- 
- Uji Multikolenearitas

Uji multikolenearitas menurut buku Eviews oleh Wing Winarto adalah kondisi adanya hubungan linear antarvariabel independen. Pengujian terhadap ada tidaknya multikolenearitas dilakukan dengan menggunakan persamaan regrasi sederhana (yang terdiri atas satu variabel dependen dan satu atau lebih variabel independen). Dalam penelitian ini, variabel dependen adalah BETA, sedangkan variabel independen adalah DOLdan DFL.

Kriteria penentuan adanya masalah atau tidak, dengan memperhatikan nilai koefisien antar variabel. Apabila hasil perhitungan koefisien antar variabel lebih besar dari 0,89 maka ada masalah pada multikolinearitas. Hasil pengujian terhadap multikolenearitas adalah sebagai berikut:

Tabel 5. Hasil Perhitungan Uji Multikolenearitas

\begin{tabular}{|l|l|l|l|}
\hline variabel & BETA & DOL & DFL \\
\hline BETA & 1 & 0.1414 & -0.1472 \\
\hline DOL & 0.1414 & 1 & 0.0706 \\
\hline DFL & -0.1472 & 0.0706 & 1 \\
\hline
\end{tabular}

Sumber: Hasil Penelitian

Berdasarkan hasil perhitungan di atas, dapat disimpulkan bahwa tidak terdapat masalah dalam uji multikolenearitas. Karena hasil tiap variabel kurang dari 0,89. Maka model dapat dilanjutkan.

- Uji Heteroskedatisitas

Berdasarkan perhitungan hasil dari uji heteroskedatisitas pada penelitian ini mendapatkan nilai probabilitas sebesar: 0,984321.

Karena angka ini lebih besar dari pada taraf signifikan yang sudah ditetapkan yaitu $0,050(5 \%)$, maka dapat disimpulkan bahwa data ini terbebas dari masalah heteroskedatisitas.

- Uji Autokorelasi

Hasil perhitungan yang dilakukan dengan uji Durbin-Watson adalah 1,357443 . Angka ini terletak di tengah 1,10 hingga 1,54 , sehingga data mengandung autokorelasi.

Hasil perbaikan dari masalah uji autokorelasi yang bentuk regresinya $D($ beta $)=D(D O L)+D(D F L)$. Nilai $D$ tersebut merupakan different dari tiap variabel.

Maka nilai dari Durbin-Watson adalah sebesar 1,980013. Angka ini terletak di antara angka $1,54-2,46$, sehingga dapat disimpulkan bahwa data sudah terbebas dari masalah autokorelasi. 


\section{Hasil Persamaan Regresi}

Hasil perhitungan analisis dengan menggunakan metode persamaan regresi sederhana pada variabel independen dan variabel dependen adalah sebagai berikut:

Tabel 6: Persamaan Regresi Sederhana

Dependent Variable: D(BETA)

Method: Least Squares

Date: 12/01/09 Time: 19:59

Sample (adjusted): 232

Included observations: 31 after adjustments

\begin{tabular}{ccccc}
\hline \hline Variable & Coefficient & Std. Error & t-Statistic & Prob. \\
\hline C & $0.017911=0.060906$ & 0.294069 & 0.7709 \\
D(DOL) & $: 0.001953$ & 0.000783 & 2.495412 & 0.0187 \\
D(DFL) & -0.038872 & 0.018286 & -2.125820 & 0.0425 \\
\hline \hline
\end{tabular}

R-squared

Adjusted R-squared

S.E. of regression

0.245166

Mean dependent var

0.018745

Sum squared resid

- Log likelihood

0.191250

S.D. dependent var

0.377075 .

0.339106

Akaike info criterion

0.766758

3.219801

Schwarz criterion

0.905531

$-8.884746$

F-statistic

1.980013 Prob(F-statistic)

4.547134

Durbin-Watson stat

0.019495

- Koefisien Determinasi

Koefisien determinasi menunjukan tingkat hubungan variabel indepienden dengan variabel dependen. Dari Tabel di atas didapatkan nilai $\mathrm{R}^{2}$ sebesar 0.245166 atau $24,5 \%$, yang berarti bahwa pengaruh dari kedua leverage (DOL, DFL) tersebut sebesar $24,5 \%$. Hal ini bearti bahwa $24,5 \%$ varian yang terjadi pada beta disebabkan oleh perubahan yang terjadi dalam DOL dan DFL, sedangkan $75,5 \%$ sisanya disebabkan oleh variabel atau hal lain yang tidak tercangkup dalam model.

- Uji F

Dari hasil perhitungan persamaan regresi, nilai probabilitas menunjukan angka 0,019495 . Angka ini lebih kecil dari pada taraf signifikan yang ditetapkan yaitu $5 \%$ atau 0,050 . Maka dari hasil ini dapat disimpulkan bahwa secara simultan variabel DOL dan DFL mempengaruhi BETA.

- Uji T

Dari tabel hasil perhitungan analisis persamaan regresi ditarik penjelasan bahwa variabel $\mathrm{C}$ (kostanta) memiliki koefisien sebesar 0,017911 . Hal ini dapat diartikan bahwa jika tidak ada variabe! bebas (DOL, DFL) yang mempengaruhi BETA, maka tingkat BETA sebesar kostanta yaitu 0,017911 . 
Untuk DOL nilai koefisiennya sebesar $0,001.953$, artinya setiap kenaikan $1 \%$ DOL mengakibatkan kenaikan BETA sebesar 0,001953. Untuk koefisien DFL sebesar $-0,038872$, maka setiap kenaikan $1 \%$ DFL mengakibatkan penurunan BETA sebesar 0,038872 .

Probabilitas DOL menunjukan angka 0,0187 angka ini kurang dari 5\% atau 0,050 artinya $D O L$ mempengaruhi BETA secara positif. Sedangkan probabilitas untuk DFL sebesar 0,0425 angka ini juga kurang dari 0,050 atau tingkat signifikan $5 \%$ maka DFL mempengaruhi BETA secara negatif. Maka hipotesis dua (H1) diterima. Hipotesis tiga (H2) ditolak.

\section{Pembahasan}

- Hasil dari perhitungan untuk hipotesis satu (1) dalam penelitian ini yang menyebutkan leverage operasi berpengaruh positif signifikan terhadap risiko sistematis. Hipotesis ini tidak sama dengan penelitian yang dilakukan oleh insiatiningsih (1998), dalam penelitiannya disebutkan bahwa leverage operasi berpengaruh positif tetapi tidak signifikan. Begitu pula dengan penelitian Sufiyati dan Ainun Na'im (1998) yang menunjukan bahwa leverage operasi tidak mempunyai pengaruh yang signifikan terhadap beta.

- Hasil dari perhitungan untuk hipotesis dua (2) yang menyebutkan bahwa leverage keuangan berpengaruh negatif signifikan terhadap risiko sistematis. Hasil ini sama dengan penelitian yang dilakukan oleh Sufiyati dan Ainun Na'im (1998) bahwa leverage keuangan memiliki pengaruh negatif yang signifikan terhadap beta. Berbeda dengan penelitian yang dilakukan oleh Isfenti Sadalia (2003) yang menunjukan hasil bahwa leverage keuangan dengan risiko sistematis terdapat pengaruh negatif tetapi tidak signifikan. Penelitian ini juga berdeda dengan penelitian yang dilakukan oleh Insiatiningsih (1998) yang menyatakan bahwa leverage keuangan (DFL) yang diukur melalui rasio antara perubahan eaming after taxes dengan perubahan earning before interest and taxes berpengaruh positif terhadap beta saham, namun tidak signifikan. Perbedaan hasi perhitungan ini mungkin disebabkan karena jumlah sampel dan rumusan perhitungan yang digunakan berbeda.

\section{E. KESIMPULAN}

Berdasarkan hasil analisis di atas, maka dapat ditarik beberapa kesimpuian. Sebagai berikut:

1) . Secara parsial (terpisah) variabel leverage operasi (DOL) mempunyai pengaruh positif signifikan terhadap risiko sistematis (BETA). Artinya apabila level DOL naik maka risiko sistematis juga mengalami kenaikan, dan sebaliknya.

2) Secara terpisah (parsial) variabel leverage keuangan (DFL) mempunyai pengaruh negatif signifikan terhadap risiko sistematis. Artinya apabila level DFL mengalami kenaikan maka risiko sistematis mengalami penurunan, dan sebaliknya. 
Kartini dan Nevsi Rizki Herine Putri: Pengaruh Level Leverage Operasi dan Leyel...'s.

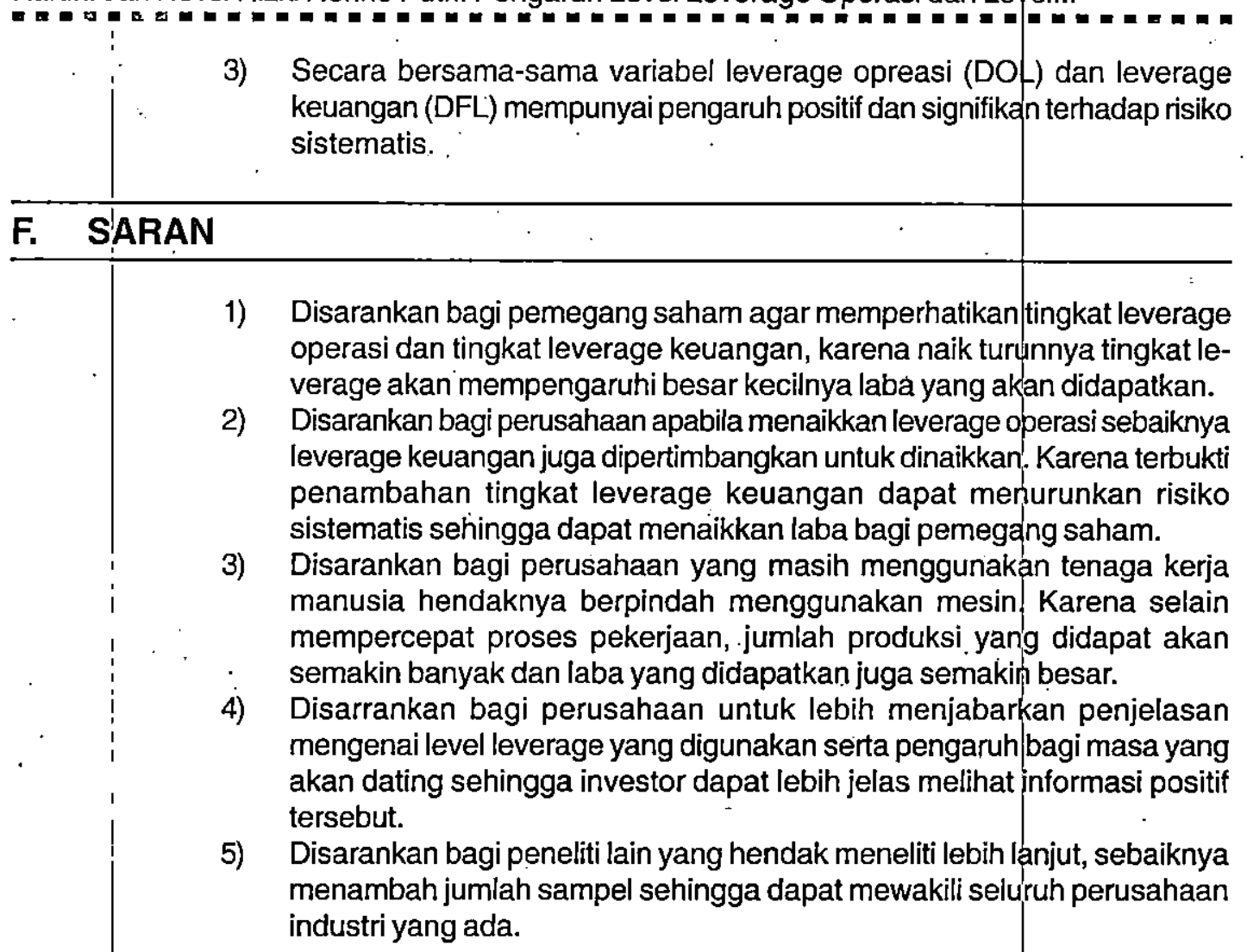

DAFTAR PUSTAKA

Brigham EF, Weston J. Fred (1998), Dasar-DasarManajemen Keuangan, Edisi Kesembilan, Erlangga, Jakarta.

Brigham, Houston (2004) Dasar - Dasar Mabajemen Keuangan, Edisi Kesepuluh, Buku Kedua, Salemba Empat, Jakarta.

Gujarati Damodar (2004), Ekonometrika Dasar, Erlangga, Jakarta

Gujarati Damodar (2007), Ekonometrika Dasar, Edisi Ketiga, Erlangga, Jakarta.

Hanafi Mamduh, (2006), Manajemen Risiko, BPFE, Yogyakarta.

Horne and Wachowicz (1995) Dasar-Dasar Manajemen Keuangan, Edisi Kelima, Erlangga, Jakarta. 
Horne James, (1994), Dasar-Dasar Manajemen Keuangan, Edisi Keenam, Erlangga, Jakarta.

Husnan Suad (2005), Dasar-Dasar Teori Portofolio dan Analisis Sekuritas, Edisi Keempat, UPP AMP YKPN, Yogyakarta.

Insiatiningsih (2001), Pengaruh Tingkat Leverage Operasi dan Leverage Keuangan Terhadap Risiko Sistematik Saham, Jurnal KEBI, hal: 821.

Jogianto (2008), Teori Portofolio dan Analisis Investasi, Edisi Kelima, BPFE, Yogyakarta.

Miswanto (2002), Pengaruh Keputusan Leverage Terhadap Laba dan Risiko, Jurnal Kajian Bisnis, 25, hal: 79-95.

Murtini Umi (2006), Pengaruh Pangsa Pasar, Rasio Leverage dan Rasio Intensitas Modal Terhadap Probabilitas Perusahaan Manufaktur yang Go-Public di Indonesia, Jurnal Riset Akuntansi dan Keuangan, 2 (1), hal: 27-36.

Sadalia Isfenti (2003), Penagruh Leverage Keuangan dan Kebijakan Keuangan Terhadap Risiko Sistematis dan Keputusan Headging Serta Nilai Perusahaan Manufaktur Terbuka, Jurnal Siasat Bisnis, 13 (20), hal: 125-153

Sufiati, Na'im Ainun (1998), Pengaruh Leverage Operasi dan Leverage Financial Terhadap Risiko Sistematik Saham, Jumal Ekonomi dan Bisnis Indonesia, 13 (3), hal: 57-69

Wahyu Wing (2009), Analisis Ekonometrika dan Statistika Dengan Eviews, Edisi Kedua, UPP STIM YKPN, Yogyakarta.

Weston Fred (1991) Manajemen Keuangan, Edisi Ketujuh, Jilid Kedua, Erlangga, Jakarta. 